\title{
Genetic Control of Efficient Nitrogen Use for High Yield and Grain Protein Concentration in Wheat: A Review
}

\author{
Wan Teng ${ }^{1}$, Xue $\mathrm{He}^{1}$ (D) and Yiping Tong ${ }^{1,2,3, *(\mathbb{D})}$ \\ 1 The State Key Laboratory for Plant Cell and Chromosome Engineering, Institute of Genetics and \\ Developmental Biology, Chinese Academy of Sciences, Beijing 100101, China; tengwan@genetics.ac.cn (W.T.); \\ hexue@genetics.ac.cn (X.H.) \\ 2 College of Advanced Agricultural Sciences, University of Chinese Academy of Sciences, Beijing 100049, China \\ 3 The Innovative Academy of Seed Design, Chinese Academy of Sciences, Beijing 100101, China \\ * Correspondence: yptong@genetics.ac.cn; Tel.: +86-10-64806556
}

Citation: Teng, W.; He, X.; Tong, Y. Genetic Control of Efficient Nitrogen Use for High Yield and Grain Protein Concentration in Wheat: A Review.

Plants 2022, 11, 492. https://doi.org/ $10.3390 /$ plants11040492

Academic Editors: Mark

D. Wilkinson, Ondrej Kosik and

Tika Adhikari

Received: 11 January 2022

Accepted: 4 February 2022

Published: 11 February 2022

Publisher's Note: MDPI stays neutral with regard to jurisdictional claims in published maps and institutional affiliations.

Copyright: (C) 2022 by the authors. Licensee MDPI, Basel, Switzerland. This article is an open access article distributed under the terms and conditions of the Creative Commons Attribution (CC BY) license (https:// creativecommons.org/licenses/by/ $4.0 /)$.

\begin{abstract}
The increasing global population and the negative effects of nitrogen $(\mathrm{N})$ fertilizers on the environment challenge wheat breeding to maximize yield potential and grain protein concentration (GPC) in an economically and environmentally friendly manner. Understanding the molecular mechanisms for the response of yield components to $\mathrm{N}$ availability and assimilates allocation to grains provides the opportunity to increase wheat yield and GPC simultaneously. This review summarized quantitative trait loci/genes which can increase spikes and grain number by enhancing $\mathrm{N}$ uptake and assimilation at relative early growth stage, and 1000-grain weight and GPC by increasing postanthesis $\mathrm{N}$ uptake and $\mathrm{N}$ allocation to grains.
\end{abstract}

Keywords: Triticum aestivum; nitrogen use efficiency; grain yield; grain protein concentration; root morphology; nitrate transporter; nitrogen assimilation

\section{Introduction}

Wheat (Triticum aestivum) is the most widely cultivated cereal in the world, providing $20 \%$ of the calories and protein in the global human diet [1]. As the world population is predicted to be over 9 billion by 2050, the demand for wheat will increase by $60 \%$ compared to 2010 [2]. Nitrogen (N) is an essential nutrient, and often the most critical yield-limiting factor in crop production [3]. Among the crops, wheat received the highest amount of $\mathrm{N}$ fertilizers, with $18.2 \%$ of global use, followed by maize with $17.8 \%$ and rice with $15.2 \%$ [4]. A global N budget assessment in cereal production systems for 50 years (1961 to 2010) revealed that approximately $44.6 \%$ of $\mathrm{N}$ harvested by wheat crops was derived from applied fertilizer-N, indicating most of the applied $\mathrm{N}$ was not used by wheat crops [5]. Fertilizer $\mathrm{N}$ not recovered by crops can cause environmental problems of nitrate pollution of waters and the pollution of the atmosphere with nitrous oxide, other oxides of $\mathrm{N}$, and ammonia [6]. The Wheat Initiative Strategic Research Agenda suggests increasing N use of over $60 \%$ of the applied amount to increase wheat production by at least $60 \%$ by 2050 [2]. Therefore, it is required to increase wheat yield in an economically and environmentally friendly manner. Such as breeding wheat with improved N use efficiency (NUE) and designing variety-specific recommendations of $\mathrm{N}$ fertilizer management [2,7-9].

The genetic control of $\mathrm{N}$ use-related traits and strategies in improving NUE in wheat have been reviewed by several authors [8,10,11]. As selecting yield and grain protein concentration (GPC) both are important in wheat breeding, and the improvement of both traits depends on efficient $\mathrm{N}$ use, this review will summarize $\mathrm{N}$ uptake and assimilation quantitative trait loci (QTL)/genes which coordinate the formation of yield and yield components and $\mathrm{N}$ allocation to grains. 


\section{Definition of N Use-Related Traits}

NUE and its components $\mathrm{N}$ uptake efficiency (NUpE) and utilization efficiency (NUtE) are defined as below [12].

$$
\begin{aligned}
\mathrm{NUE} & =\frac{\mathrm{GY}}{\mathrm{Ns}} \\
\mathrm{NUpE} & =\frac{\mathrm{Gt}}{\mathrm{Ns}} \\
\mathrm{NUtE} & =\frac{\mathrm{GY}}{\mathrm{Nt}}
\end{aligned}
$$

where GY is grain yield per unit area, $\mathrm{Nt}$ is total $\mathrm{N}$ in the plant (grain + stove) at maturity per unit area, and $\mathrm{Ns}$ is $\mathrm{N}$ supply or rate of fertilizer $\mathrm{N}$ per unit area. GY, Nt, and $\mathrm{Ns}$ are all expressed in the same units.

$\mathrm{N}$ harvest index (NHI) can be expressed as:

$$
\mathrm{NHI}=\frac{\mathrm{GY} \times \mathrm{GNC}}{\mathrm{Nt}}
$$

where GNC is grain $\mathrm{N}$ concentration. According to the above four equations, we can get the following equations:

$$
\begin{gathered}
\mathrm{NUE}=\mathrm{NUpE} \times \mathrm{NUtE} \\
\mathrm{GY}=\mathrm{NUtE} \times \mathrm{Nt}=\frac{\mathrm{GY}}{\mathrm{Nt}} \times \mathrm{Nt} \\
\frac{\mathrm{NUtE}}{\mathrm{NHI}}=\frac{\mathrm{GY}}{\mathrm{GY} \times \mathrm{GNC}}=\frac{1}{\mathrm{GNC}} \text { or NUtE }=\frac{\mathrm{NHI}}{\mathrm{GNC}}
\end{gathered}
$$

\section{Genetic Gain for N Use- and Yield-Related Traits}

Understanding historical trends in $\mathrm{N}$ use-related traits during wheat breeding is important to design strategy in improving the NUE of future varieties while maximizing yield potential and GPC [13]. Although wheat breeding was in most cases not targeted to improve NUE [7], significant genetic gains have been observed for $\mathrm{N}$ use-related traits around the world (Table 1). The rates of genetic gain for NUpE, NUtE, $\mathrm{N}$ harvest index, and post-anthesis $\mathrm{N}$ uptake were comparable in wheat main production regions, including China, Europe, and the United States (Table 1). The four studies listed in Table 1 all observed a much lower rate of genetic gain for NUpE and NUtE than for grain yield, and a lower rate for $\mathrm{N}$ harvest index than for harvest index. These data indicate that $\mathrm{NUpE}$, $\mathrm{NUtE}$, and $\mathrm{N}$ harvest index have great potential to be improved in future wheat breeding.

\begin{tabular}{|c|c|c|c|c|}
\hline Area & China & European & The United States & South-Eastern Europe \\
\hline Variety released year & 1937 2012 & $1985 \sim 2010$ & 1960 2014 & 1936 2016 \\
\hline Reference & [14] & [15] & [16] & [13] \\
\hline Grain yield & $0.65 \%$ & $0.45 \%$ & $\begin{array}{l}0.331 \% \text { in } 2012 \\
0.761 \% \text { in } 2013\end{array}$ & $\begin{array}{l}+0.31 \% \text { at } \mathrm{LN} \\
+0.34 \% \text { at } \mathrm{HN}\end{array}$ \\
\hline Biomass yield & Stable & & & \\
\hline Grain number & $0.16 \%$ & & & \\
\hline 1000-grain weight & $0.38 \%$ & Stable & & \\
\hline
\end{tabular}
Considering that GNC is negatively correlated with NUtE (Equation (7)) and GPC (GPC $=5.7 \times \mathrm{GNC}$ ) is a key element of wheat end-use value, NUtE should be improved by increasing $\mathrm{N}$ harvest index ( $\mathrm{N}$ remobilization), but not by reducing GNC or GPC. As such, scientists should explore genes that can increase $\mathrm{NUpE}$ and more efficiently allocate the absorbed $\mathrm{N}$ to grains to simultaneously improve both yield and GPC.

Table 1. The rates of genetic gain (\% per year) for yield- and N-use-related traits in wheat. 
Table 1. Cont.

\begin{tabular}{|c|c|c|c|c|}
\hline Area & China & European & The United States & South-Eastern Europe \\
\hline Spike number & Stable & Stable & & \\
\hline Harvest index & $0.62 \%$ & $0.13 \%$ & & $\begin{array}{l}0.24 \% \text { at } \mathrm{LN} \\
0.28 \% \text { at } \mathrm{HN}\end{array}$ \\
\hline Grain N/protein concentration & Stable & Stable & & $\begin{array}{l}-0.10 \% \text { at } \mathrm{LN} \\
-0.10 \% \text { at } \mathrm{HN}\end{array}$ \\
\hline $\mathrm{N}$ harvest index & $0.17 \%$ & $0.12 \%$ & $\begin{array}{l}0.05 \% \text { in } 2012 \\
0.20 \% \text { in } 2013\end{array}$ & $\begin{array}{l}0.07 \% \text { at } \mathrm{LN} \\
0.07 \% \text { at } \mathrm{HN}\end{array}$ \\
\hline $\mathrm{N}$ uptake efficiency & $0.25 \%$ & Not evaluated & $\begin{array}{l}0.076 \% \text { in } 2012 \\
0.165 \% \text { in } 2013\end{array}$ & $\begin{array}{l}0.15 \% \text { at } \mathrm{LN} \\
0.12 \% \text { at } \mathrm{HN}\end{array}$ \\
\hline $\mathrm{N}$ utilization efficiency & $0.31 \%$ & $0.20 \%$ & $\begin{array}{l}0.115 \% \text { in } 2012 \\
0.367 \% \text { in } 2013\end{array}$ & $\begin{array}{l}0.15 \% \text { at } \mathrm{LN} \\
0.20 \% \text { at } \mathrm{HN}\end{array}$ \\
\hline Post-anthesis N uptake & & & $\begin{array}{c}2.95 \% \text { in } 2012 \\
0.485 \% \text { in } 2013\end{array}$ & $\begin{array}{l}0.38 \% \text { at } \mathrm{LN} \\
0.51 \% \text { at } \mathrm{HN}\end{array}$ \\
\hline $\mathrm{N}$ partial factor productivity & $0.64 \%$ & & & \\
\hline $\mathrm{N}$ agronomic efficiency & $0.68 \%$ & & & \\
\hline
\end{tabular}

HN and LN indicate high- and low-N treatment, respectively.

\section{Associations of N Uptake and Assimilation Genes with Meta-QTL for N Use- and Yield-Related Traits}

Nitrate is the main $\mathrm{N}$ resource for wheat. Nitrate uptake by roots is mediated by the low-affinity transport system encoded by NRT1/NPF family genes and the high-affinity transport system encoded by NRT2 family genes. Once nitrate enters plant cells, it is reduced to nitrite by nitrate reductase (NR) in the cytosol, and nitrite is then translocated to the plastids and reduced to ammonium by the nitrite reductase (NiR). Ammonium can be assimilated into glutamine (Gln) and glutamate (Glu) through the glutamine synthetase (GS)/glutamate synthase (GOGAT) cycle [17].

The wheat genome contains 331 NRT1/NPF and 46 NRT2 genes [18,19]; however, only a few of these transporters have been functionally characterized. The two NPF genes (TraesCS1B02G038700 and TraesCS1D02G214200) and one NRT2 gene (TraesCS6A02G030800) displayed nitrate transport activity when expressed in Xenopus oocytes [18]. TraesCS1D02G2 14200 (TaNRT1.1B-1D2) is closely linked with a meta-QTL for yield-related traits (Table 2) and is an orthologue of rice OsNRT1.1B. The elite allele of OsNRT1.1B can improve NUE and grain yield of rice (Oryza sativa) [20]. TaNRT2.5-3B required a partner protein TaNAR2.1 to give nitrate transport activity in oocytes and mediated long-distance transportation of nitrate from roots to grains [21]. TaNRT2.1-6B encoded a dual-affinity nitrate transporter and was associated with $\mathrm{N}$ harvest index and grain yield. Overexpressing TaNRT2.1-6B increased grain yield and $\mathrm{N}$ uptake under low- and high- $\mathrm{N}$ conditions in a pot experiment [22]. Genotyping of a panel of 254 diverse wheat cultivars and landraces by the wheat 660k Axiom Array indicated that wheat breeding did not affect the polymorphisms of most of the NPF and NRT2 genes [18]. When comparing the physical positions of the NRT1/NPF and NRT2 genes with the locations of meta-QTL for N use- and yield-related traits $[11,23,24]$, we found that several NPF and NRT2 genes are located in the interval of the meta-QTL (Table 2), providing cues for exploring the contribution of $\mathrm{N}$ transporters to the natural variation in $\mathrm{N}$ use- and yield-related traits. 
Table 2. The N uptake and assimilation genes are linked with meta-QTL for N use- and yield-related traits.

\begin{tabular}{|c|c|c|c|c|c|}
\hline Gene & $\begin{array}{c}\text { PhPosition } \\
\text { on RefSeq V1.0 }\end{array}$ & Gene Name & $\begin{array}{c}\text { Meta-QTL } \\
\text { for Yield [23] }\end{array}$ & $\begin{array}{c}\text { Meta-QTL } \\
\text { for Yield }^{\mathbf{b}} \text { [24] }\end{array}$ & $\begin{array}{c}\text { Meta-QTL } \\
\text { for NUE/RSA }\end{array}$ \\
\hline \multicolumn{6}{|l|}{$\mathrm{N}$ transport } \\
\hline TraesCS4B02G029600 & 4B:21928977-21936945 & NPF2.4-4B & $\checkmark$ & & \\
\hline TraesCS4D02G026800 & 4D:11862455-11867655 & NPF2.4-4D & $\checkmark$ & & \\
\hline TraesCS3B02G095900 & 3B:64314648-64316600 & NPF6.1-3B & $\checkmark$ & & \\
\hline TraesCS1A02G031300 & 1A:14519757-14525659 & NPF6.2-1A & & & $\checkmark$ \\
\hline TraesCS2D02G182900 & 2D:127113821-127117419 & NPF7.1-2D & & & $\checkmark$ \\
\hline TraesCS7D02G297000 & 7D:374564870-374572229 & NRT1.1A-7D & & $\checkmark$ & \\
\hline TraesCS1D02G214200 & 1D:299575952-299578670 & NRT1.1B-1D2 & & $\checkmark$ & \\
\hline TraesCS5A02G537100 & 5A:693632703-693642408 & NRT1.1C-5A & $\checkmark$ & & \\
\hline TraesCS2A02G074800 & 2A:33054150-33056031 & NRT2.3-2A & & $\checkmark$ & $\checkmark$ \\
\hline TraesCS2D02G073500 & 2D:30787486-30789242 & NRT2.3-2D & $\checkmark$ & $\checkmark$ & \\
\hline TraesCS3A02G254000 & 3A:475304797-475306341 & NRT2.5-3A & $\checkmark$ & & \\
\hline TraesCS7A02G428500 & 7A:621910950-621913739 & NRT2.6-7A & & $\checkmark$ & \\
\hline TraesCS7B02G328700 & 7B:583923053-583926829 & NRT2.6-7B & & & $\checkmark$ \\
\hline TraesCS7D02G420900 & 7D:540617018-540627808 & NRT2.6-7D & $\checkmark$ & & \\
\hline NRT2 cluster & 6A:15727844-16410137 & $13 \mathrm{NRT} 2 \mathrm{~s}$ & & & $\checkmark$ \\
\hline \multicolumn{6}{|l|}{$\mathrm{N}$ assimilation } \\
\hline TraesCS4A02G376700 & 4A:651365942-651370213 & NR1.2-4A & & $\checkmark$ & $\checkmark$ \\
\hline TraesCS7A02G078500 & 7A:43180494-43185382 & NR1.2-7A & & & $\checkmark$ \\
\hline TraesCS7D02G073700 & 7D:43212472-43217253 & NR1.2-7D & & & $\checkmark$ \\
\hline TraesCS6A02G017500 & 6A:8694483-8700180 & NR1.1-6A & $\checkmark$ & & \\
\hline TraesCS6B02G024900 & 6B:15128191-15134280 & NR1.1-6B & $\checkmark$ & & \\
\hline
\end{tabular}


Table 2. Cont.

\begin{tabular}{|c|c|c|c|c|c|}
\hline Gene & $\begin{array}{c}\text { PhPosition } \\
\text { on RefSeq V1.0 }\end{array}$ & Gene Name & $\begin{array}{l}\text { Meta-QTL } \\
\text { for Yield [23] }\end{array}$ & $\begin{array}{c}\text { Meta-QTL } \\
\text { for Yield }^{\mathbf{b}}[24]\end{array}$ & $\begin{array}{c}\text { Meta-QTL } \\
\text { for NUE/RSA [11] }\end{array}$ \\
\hline TraesCS6D02G020700 & 6D:8149929-8155961 & NR1.1-6D & $\checkmark$ & & $\checkmark$ \\
\hline TraesCS6A02G333900 & 6A:564882616-564886300 & $N i R-6 A$ & $\checkmark$ & $\checkmark$ & \\
\hline TraesCS6A02G298100 & 6A:531394366-531398363 & GS1.1-6A & $\checkmark$ & & \\
\hline TraesCS4B02G04740 & 4B:34722272-34725256 & GS1.3-4B & $\checkmark$ & $\checkmark$ & \\
\hline TraesCS4D02G047400 & 4D:22946578-22949866 & GS1.3-4D & $\checkmark$ & & \\
\hline TraesCS2B02G528300 & 2B:722629776-722634436 & GS2-2B & $\checkmark$ & $\checkmark$ & \\
\hline TraesCS2A02G130600 & 2A:78328734-78346097 & FD-GOGAT-2A & & $\checkmark$ & \\
\hline TraesCS2D02G132900 & 2D:78375985-78392563 & FD-GOGAT-2D & & $\checkmark$ & \\
\hline TraesCS3A02G266300 & 3A:490922100-490932750 & NADH-GOGAT-3A & $\checkmark$ & & $\checkmark$ \\
\hline
\end{tabular}

${ }^{a}$ The physical positions were retrieved from http:/ / wheat.cau.edu.cn/TGT/, accessed on 10 December 2021. ${ }^{\mathrm{b}}$ The meta-QTL was analyzed based on QTL related to wheat yield under irrigated, drought- and/or heat-stressed conditions. RSA root system architecture. 
Analysis of Chinese Spring reference sequence (http:/ / plants.ensembl.org/Triticum_ aestivum/Info/Index, accessed on 15 December 2021) revealed that the genes encoding NR, NiR, GS, and GOGAT all present in a small gene family in wheat, with three TaNRs, one TaNiR, three cytosolic TaGS1s, one plastic TaGS2, and two GOGATs in each of the wheat sub-genomes. As a small number of primary $\mathrm{N}$-assimilation genes mediate the assimilation of the inorganic $\mathrm{N}$ absorbed by wheat plants into amino acids, they should have a critical role in determining NUE in wheat. When comparing the physical positions of these primary $\mathrm{N}$-assimilation genes with the locations of meta-QTL for $\mathrm{N}$ use- and yield-related traits $[11,23,24]$, we found that 15 of these $30 \mathrm{~N}$-assimilation genes locate in the interval of the meta-QTL (Table 2). Cross-genome meta-QTL analysis also revealed the crucial role of N-assimilation genes in mediating NUE in crops including wheat [25]. Haplotype variations of TaGS2-2A, $-2 B$ and $-2 D$ were associated with root system architecture-, $\mathrm{N}$ use- and yield-related traits [26], and the elite allele of TaGS2-2Ab has been successfully used to engineer wheat with improved NUE and yield under both high- and low-N conditions [27]. TaNADH-GOGAT-3B has been suggested as a candidate contributing to the natural variation of NUE in wheat [25], more recently overexpression of TaNADHGOGAT-3B has been shown to increase $\mathrm{N}$ uptake and yield in wheat [28]. In rice, allelic variation at $O s N R 2$ contributed to the difference in nitrate assimilation capacity and NUE between the indica and japonica rice subspecies, with indica OsNR2 exhibiting greater NR activity [29]. The elite allele of OsNiR1 with increased NiR activity significantly improved rice regeneration [30], and increasing OsNiR1 expression enhanced NUE by promoting spike number in rice [31]. In maize (Zea mays), the GS1 genes ZmGln1.3 and 1.4 linked with QTL for NUE-related traits and were specifically involved in the control of kernel number and kernel size, respectively [32]. As only a few of the $\mathrm{N}$-assimilation genes have been characterized by their biological functions and allelic variations in wheat, their contribution to the genotypic difference in NUE has yet to be explored in the future.

It is worthy to notice that several $\mathrm{N}$ transport and assimilation genes are located in the interval of meta-QTL for the yield-related trait under drought and heat stress (Table 2). Wheat crops are grown in environments that are prone to drought and heat stress [33]. Drought and heat stresses are known to have adverse effects on $\mathrm{N}$ uptake and assimilation [34-36]. For example, short-term heat stress greatly inhibited NR activity and photosynthetic $\mathrm{N}$ use efficiency of wheat plants [35]. Drought stress considerably reduced the contents of total protein, Rubisco, and GS2 isoenzyme in wheat leaves, and GS has been suggested as a good indicator in characterizing wheat cultivars in terms of drought stress tolerance [34]. Recently, overexpression of wheat cytosolic and plastid glutamine synthetases has been shown to enhance drought tolerance in tobacco (Nicotiana tabacum) [37]. As such, selecting for $\mathrm{N}$ use efficient wheat varieties may increase yield stability under drought and heat stress conditions.

\section{N Uptake and Assimilation for Increasing Spikes and Grain Number}

To obtain higher wheat yield and GPC with less N input, it is important to understand the timing of $\mathrm{N}$ uptake and wheat development in relation to the formation of yield components. The grain yield can be expressed as:

Grain yield $=$ spike number $\times$ spikelet number per spike $\times$ fertile floret number per spikelet $\times$ grain weight

Wheat development can be divided into seedling growth, tillering, stem elongation, booting/ear emergency, flowering, and ripening, the tillering and stem elongation stages are critical in determining fertile spikes and grain number, while the duration and rate of grain filling determine 1000-grain weight [38]. It is well known that $\mathrm{N}$ fertilizer increases grain yield mainly by increasing spike number and grain number. $\mathrm{N}$ application rate and timing greatly affected spike number, spikelet number per spike, and fertile floret number per spikelet [39-42], and $\mathrm{N}$ concentration and accumulation in both spike and non-spike organs were significantly positively correlated with grain number at stem elongation [40]. 
As such, $\mathrm{N}$ application and efficient $\mathrm{N}$ uptake at the relative early growth stage are then critical for increasing spikes and grain number.

It has been reported that winter wheat roots are mostly established during the fall growing season, supporting $\mathrm{N}$ uptake demand for rapid above-ground growth in early spring [43], and vigorous early root growth has been shown as a major factor influencing $\mathrm{N}$ uptake [44]. Studies on the historical and modern wheat varieties in the wheat main production areas in China revealed that the genetic gain in $\mathrm{N}$ uptake (aerial $\mathrm{N}$ accumulation amount) mainly raised during stem elongation phase, explaining the significant genetic gains in grain number per spike and per unit area (spike number per unit area $\times$ grain number per spike) $[45,46]$. Therefore, understanding the molecular mechanism underlying the roots' efficient $\mathrm{N}$ acquisition of wheat seedlings may improve NUE and yield by increasing spikes and grain number. Based on our best knowledge, we listed QTL/genes which can increase root growth and nitrate influx rate of wheat seedlings in Table 3 , and summarized their effects on $\mathrm{N}$ use- and yield-related traits of mature plants grown under field conditions. These QTL/genes mediated root growth, $\mathrm{N}$ influx rate, and $\mathrm{N}$ assimilation of wheat seedlings, and had positive effects on N use-related traits (N uptake, GNC, N harvest index) and yield-related traits (grain yield, spike number, grain number, 1000grain weight, and harvest index) of mature plants (Table 3). The major QTL qTaLRO-2B coincided with QTL for N uptake and grain yield under low-N conditions, and increased both primary and lateral root length with reduced root diameter, suggesting that this QTL produces a deep and large root system with low carbon cost. In maize, steep, cheap, and deep roots have been suggested as an ideotype for optimizing $\mathrm{N}$ acquisition by maize crops [47]. As such, $q$ TaLRO-2B may be an ideal locus for wheat breeding with improved NUE and grain yield. The response of root system architecture to $\mathrm{N}$ availability is critical for root $\mathrm{N}$ foraging [48]. The auxin biosynthetic Tryptophan Aminotransferase-Related TAR2 is required for low $\mathrm{N}$-stimulated lateral root branching [49,50]. Overexpressing TaTAR2.1-3A in wheat enhanced lateral root branching, spike number, grain yield, and $\mathrm{N}$ uptake at low- and high-N while reducing TaTAR2.1 expression through RNAi had the opposite effects [49]. The rice NUE QTL $q D N R 1$ (Dull Nitrogen Response 1) encodes a putative pyridoxal phosphate-dependent transferase and functions in auxin homeostasis, knockout of OsDNR1 promoted auxin biosynthesis and consequently induced AUXIN RESPONSE FACTOR-mediated activation of $\mathrm{N}$ uptake and $\mathrm{N}$-metabolism genes, leading to improved rice yield under moderate levels of $\mathrm{N}$ fertilizer input [51]. As such, auxin metabolism and signaling have a crucial role in regulating $\mathrm{N}$ use in cereal crops.

Table 3. QTL/genes controlling root system architecture (RSA)- and N uptake-related traits of wheat seedlings.

\begin{tabular}{|c|c|c|c|c|}
\hline QTL/Gene Name & $\begin{array}{l}\text { RSA-Related Traits of } \\
\text { Wheat Seedlings }\end{array}$ & N Use-Related Traits & Yield-Related Traits & Reference \\
\hline$q T a L R O-2 B$ & $\begin{array}{c}\text { RDW-HN\&LN, } \\
\text { MRL-HN\&LN, PRL, } \\
\text { PRE, LRL, TRL, RD(-) }\end{array}$ & NUP & GY-LN, BY-LN, & {$[52-55]$} \\
\hline$q M R L-7 B$ & $\begin{array}{l}\text { RDW, MRL, TRL, and } \\
\text { RT at HN and LN }\end{array}$ & NUP and NHI at $\mathrm{HN}$ and $\mathrm{LN}$ & $\begin{array}{c}\text { GY and TGW at HN } \\
\text { and LN }\end{array}$ & {$[55,56]$} \\
\hline TaTAR2.1-3A & $\begin{array}{l}\text { LRL and RT at HN and } \\
\text { LN }\end{array}$ & NUP at $\mathrm{HN}$ and $\mathrm{LN}$ & $\begin{array}{l}\text { BY, GY, and SN at HN } \\
\text { and LN }\end{array}$ & [49] \\
\hline TaNFYA-6B & LRL & $\begin{array}{c}\text { TAR2, NPF8.3-7D, NRT2.1-6B. } \\
\text { Nitrate influx rate at LN, GNC-HN, } \\
\text { NUP at } \mathrm{HN} \text {, and LN }\end{array}$ & $\begin{array}{l}\mathrm{BY}, \mathrm{GY} \text {, and } \mathrm{SN} \text { at } \mathrm{HN} \\
\text { and LN }\end{array}$ & [57] \\
\hline
\end{tabular}


Table 3. Cont.

\begin{tabular}{|c|c|c|c|c|}
\hline QTL/Gene Name & $\begin{array}{l}\text { RSA-Related Traits of } \\
\text { Wheat Seedlings }\end{array}$ & N Use-Related Traits & Yield-Related Traits & Reference \\
\hline TaNAC2-5A & $\begin{array}{l}\text { RDW at LN } \\
\text { Seedling vigor }\end{array}$ & $\begin{array}{l}\text { NPF7.9-6D (former named as } \\
\text { NPF7.1-6D), NRT2.1-6B, TaNRT2.5, } \\
\text { TaGS2-2A. Nitrate influx rate at HN } \\
\text { and LN. GNC, grain nitrate } \\
\text { concentration, NUP, and NHI at HN } \\
\text { and LN }\end{array}$ & $\begin{array}{l}\text { GY and SN at } \mathrm{HN} \text { and } \\
\text { LN. SDW and TN of } \\
\text { wheat seedlings at HN } \\
\text { and LN. }\end{array}$ & {$[21,58]$} \\
\hline TaNRT2.5-3B & $\begin{array}{c}\text { Seedling vigor, } \\
\text { LRL-HN\&LN, PRL-LN }\end{array}$ & $\begin{array}{l}\text { Nitrate influx rate at } \mathrm{HN} \text { and } \mathrm{LN} \text {. } \\
\mathrm{NUP} \text {, grain nitrate concentration }\end{array}$ & GY, SN & [21] \\
\hline $\mathrm{TaGS} 2-2 A b$ & $\begin{array}{l}\text { MRL and LRL at HN } \\
\text { and LN }\end{array}$ & $\begin{array}{c}\text { NRT2.1, NPF6.3, Nitrate influx rate } \\
\text { at HN and LN; SNC at stem } \\
\text { elongation, flowering, } 14 \text { days after } \\
\text { flowering at HN and LN; LNC and } \\
\text { Pn of flag leaves during grain filling } \\
\text { at HN and LN; NUP, GNC, NHI, } \\
\text { and LNC (-) at maturity at HN and } \\
\text { LN. }\end{array}$ & $\begin{array}{c}\text { GY, SN, GN, TGW, and } \\
\text { HI at HN; net } \\
\text { photosynthesis rate of } \\
\text { flag leaves at HN and } \\
\text { LN }\end{array}$ & [27] \\
\hline TaNADH-GOGAT-3B & MRL, LRL & NUP & BY, GY, SN & [28] \\
\hline \multicolumn{5}{|c|}{$\begin{array}{l}\text { RSA-related traits: MRL maximum root length, PRL primary root length, LRL lateral root length, TRL total root } \\
\text { length, PRE primary root elongation rate, RD, root diameter, RT root tip number. N use-related traits: NUP N } \\
\text { uptake, NCT, N concentration, GNC grain N concentration, SNC shoot N concentration, LFC leaf N concentration } \\
\text { Pn net photosynthesis rate, NHI N harvest index. Yield-related traits: BY biomass yield, GY grain yield, SDW } \\
\text { shoot dry weight, SN spike number, TN tiller number, TGW 1000-grain weight, HI harvest index. N treatment } \\
\text { HN high N treatment, LN low N treatment. The negative mark in paragraph (-) after a trait indicates the negative } \\
\text { effect of the QTL/gene on that trait. }\end{array}$} \\
\hline
\end{tabular}

Although vigorous early root growth has been shown as a major factor influencing $\mathrm{N}$ uptake, the high-vigor wheat lines (38-19, 92-11, and CV97) showed a lower nitrate influx rate than the low-vigor commercial variety Janz, suggesting that the genotypic variation in nitrate uptake capacity (per unit of the root) offset differences in morphological traits and should be considered in efforts to improve $\mathrm{N}$ uptake [59]. Vigorous root growth with a high nitrate uptake capacity is then promising in increasing NUE and grain yield. The nitrate transporter TaNRT2.5-3B, N-assimilation gene TaGS2-2A, and the transcription factors TaNFYA-6B and TaNAC2-5A have been shown to enhance root growth as well as nitrate influx rate of wheat seedlings, and consequently increased $\mathrm{N}$ use- and yield-related traits (Table 3).

It has been mentioned above that overexpressing TaNADH-GOGAT-3B increased $\mathrm{N}$ uptake, spike number, and grain yield. The expression of TaNADH-GOGAT was negatively regulated by the ABRE-binding factor (ABF)-like leucine zipper transcription factor TabZIP60-6D, reducing TabZIP60 expression though RNAi increased NADH-GOGAT activity, $\mathrm{N}$ uptake, spike number, and grain yield, while overexpressing TabZIP60-6D had opposite effects [28]. In rice, OsARE1 is a genetic suppressor of a rice $f d$-gogat mutant defective in $\mathrm{N}$ assimilation, and knockout of $A R E 1$ increased rice yield under low- and high-N conditions [60]. Recently, CRISPR/Cas9-mediated targeted mutagenesis has been used to generate a series of transgene-free mutant lines with partial or triple-null mutation of the three TaARE1 homoeologs from the elite winter wheat variety Zhengmai 7698. All the mutant lines displayed higher spike number, grain number, 1000-grain weight, and grain yield than the wild type under field conditions [61]. As such, the identification of genes negatively regulating $\mathrm{N}$ assimilation provides the opportunity to engineer wheat with improved NUE and yield through a genome editing approach.

\section{N Uptake and Assimilation for Increasing Yield and Grain Protein Concentration}

One of the challenges in wheat breeding is to simultaneously improve both yield and GPC because of the strong negative relationship between these two traits [62]. Several 
studies on historical and modern wheat varieties revealed significant genetic gain in grain yield, but not in GPC (Table 1). However, there is a genotypic difference in grain protein deviation, the deviation from the regression line between grain yield and GPC, and grain protein deviation has been suggested as a selection criterion for wheat breeding with increased grain yield and GPC [16,62-64]. QTL for grain protein deviation has been detected in common wheat and durum wheat, and several N-related genes were found to be linked with QTL for grain protein deviation $[65,66]$, suggesting a genetic opportunity for increasing grain yield and GPC simultaneously.

Grain N originates from remobilization of $\mathrm{N}$ accumulated in vegetative tissues preanthesis and $\mathrm{N}$ uptake post-anthesis. Several studies pointed out the importance of postanthesis $N$ uptake in determining grain protein deviation and GPC $[16,63,64,67,68]$. It has been reported that post-anthesis $\mathrm{N}$ uptake was associated with expression of TaNRT2 members, such as TaNRT2.1 and TaNRT2.2 on group 6 chromosomes, TaNRT2.3 on group 2 chromosomes, TaNRT2.4 on group 1 chromosomes, TaNRT2.5 on group 3 chromosomes, TaNRT2.6 on group 7 chromosomes, and NRT2 partner genes TaNAR2 [21,62,69]. The TaNRT2.5-TaNAR2.1 complex had nitrate transport activity in Xenopus oocytes and was located to the tonoplast in a tobacco leaf transient expression system. TaNRT2.5 and the root-specific TaNRT2.1 had comparable mRNA abundance in roots at the grain filling stage. Overexpressing TaNRT2.5-3B increased post-anthesis $\mathrm{N}$ uptake and grain yield without reducing GNC [21]. The nitrate-inducible NAC transcription factor TaNAC2-5A directly regulates the expression of TaNRT2.5 and TaNRT2.1, and overexpression of TaNAC2-5A significantly increased nitrate influx rate, $\mathrm{N}$ uptake, GNC, and grain yield under both low- and high-N conditions [58]. As such, manipulating TaNRT2 expression shows great potential in increasing grain yield and GPC simultaneously.

Although several QTL for root system architecture-related traits were associated with $\mathrm{N}$ use-related traits [11], their contribution to $\mathrm{N}$ use was largely not validated. A recent study has investigated the effects of $Q M r l-7 B$ on $\mathrm{N}$ use and yield by using near-isogenic lines (NILs). QMrl-7B was a major stable QTL controlling the maximum root length of wheat seedlings and was linked with a QTL for N uptake at maturity [55]. When a set of QMrl-7B NILs with superior and inferior alleles was grown under field conditions in two consecutive growing seasons, the NILs with the superior allele had larger and deeper root system from seedling stage to maturity, greater $\mathrm{N}$ uptake after stem elongation, and higher grain yield, 1000-grain weight, harvest index, GNC and N harvest index at maturity than those with the inferior allele under high- and low-N conditions [56]. These results indicate that $Q M r l-7 B$ is valuable in increasing grain yield and GPC. Besides $Q M r l-7 B$, several key determiners for wheat development also have a crucial role in controlling root system architecture. The Green Revolution Rht1 genes have been found to reduce root biomass [70]. Whereas introducing the 1 RS alien translocation into modern varieties can greatly increase shallow and deep root biomass and uptake of $\mathrm{N}[71,72]$. The VERNALIZATION1 (VRN1) gene responsible for spring-winter growth habit is a key determiner in controlling root system architecture and NUE in wheat $[73,74]$, the winter allele of $V R N 1$ leads the winter wheat a narrower root angle than the spring wheat [73]. Since the RHT1 and VRN1 genes are important for wheat adaptation to local growing conditions, understanding their interactions with $\mathrm{N}$ signaling will facilitate the precise design of N-efficient wheat varieties according to the prevalent allele(s) of RHT1 and VRN1 genes in different wheat ecological regions.

It has been reported that GS-mediated $\mathrm{N}$ assimilation is one of the main checkpoints controlling the $\mathrm{N}$ status of the plant and $\mathrm{N}$ remobilization for grain filling [75]. In wheat leaves, GS2 is the major GS isoform [76-78], but it experiences rapid loss during grain filling $[76,78]$. Two studies in China showed that wheat breeding increased grain yield but reduced GNC, and increased $\mathrm{N}$ uptake during stem elongation phase but not after anthesis [45,46], possibly because that wheat breeding increased leaf GS activity at stem elongation and anthesis but not at grain filling [46]. As such, low GS2 activity during grain filling may be a limiting factor for increasing post-anthesis $\mathrm{N}$ uptake and GPC. This 
assumption was evidenced by the study of transgenic expressing the elite allele TaGS2-2Ab under the control of its native promoter. Compared with the wild type, the transgenic lines had higher expression of TaGS2 in shoots and roots of the seedlings, and higher GS2 protein abundance and GS activity in flag leave when checked at 14 days post-anthesis [27]. The increased grain yield, GNC, harvest index, and N harvest index of the transgenic lines meet the requirement for an $\mathrm{N}$ efficient wheat ideotype [79]. These merits of the transgenic lines were associated with increased root growth and nitrate influx rate possibly by up-regulating TaNRT2.1 and TaNPF6.3 expression, N uptake before and after anthesis, $\mathrm{N}$ remobilization, and leaf functional duration (Figure 1). The expression of TaGS2-2A was directly regulated by TaNAC2-5A, overexpression of TaNAC2-5A increased grain yield, GNC, and $\mathrm{N}$ harvest index [58]. As such, the identification of genes regulating TaGS2 expression and GS2 activity may provide more gene resources for improving grain yield and GPC.

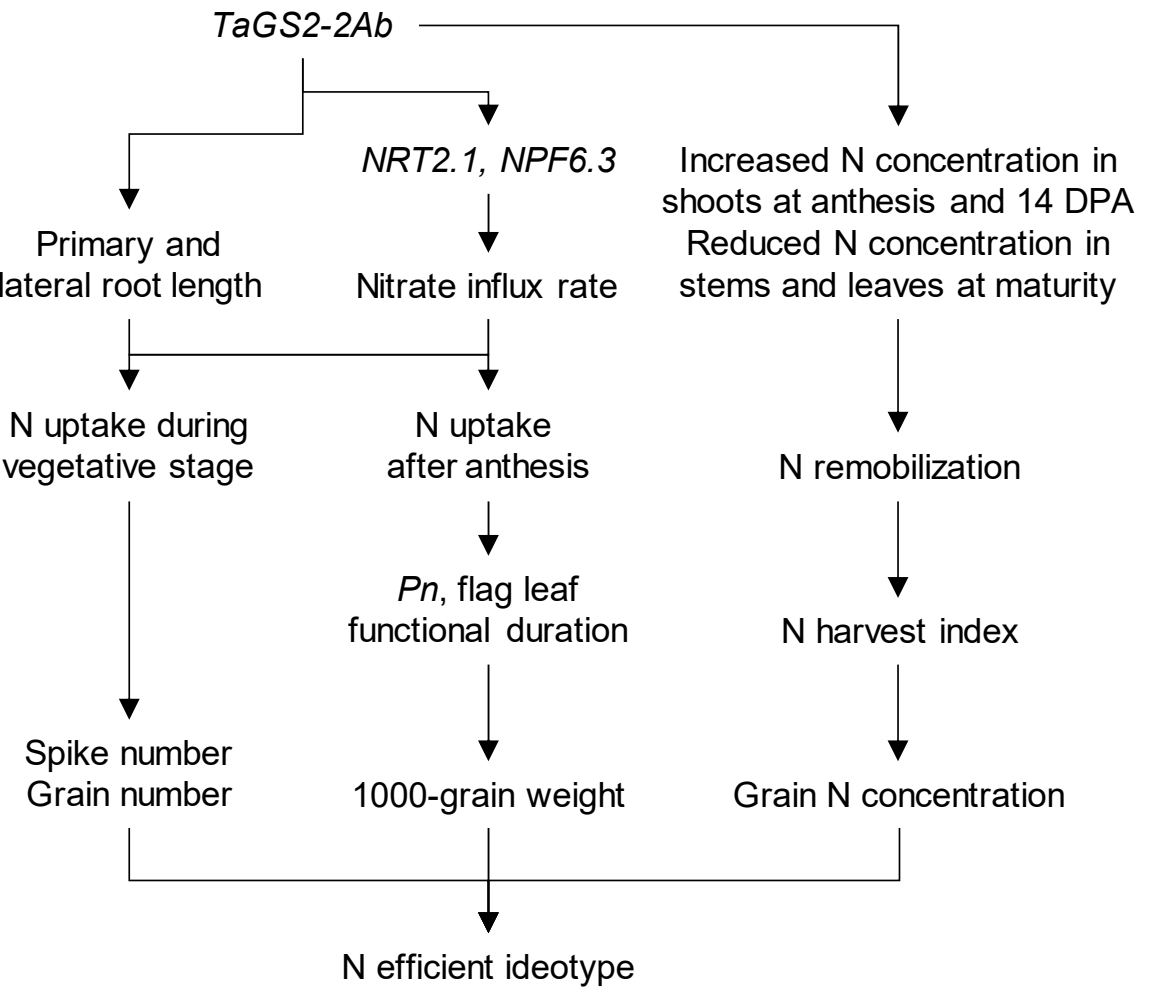

Figure 1. $\mathrm{N}$ efficient wheat ideotype mediated by the elite allele TaGS2-2Ab.

Besides GS2, NR encoding genes also showed potential in improving grain yield and GPC. All the six NR1 genes are located in the interval of the meta-QTL for N use- and yieldrelated traits (Table 3). Compared with the low NR wheat genotype, the high NR genotype had increased $\mathrm{N}$ harvest index and GNC without yield penalty [80]. Overexpression of a tobacco NR gene in wheat increased 1000-grain weight and GPC [81]. In rice, overexpression of the elite allele of OsNR2 from indica rice increased grain yield and $\mathrm{N}$ concentration in panicle [29].

Efficient $\mathrm{N}$ uptake and assimilation increase spikes and grain numbers, and efficient $\mathrm{N}$ uptake and remobilization during grain filling benefit higher grain weight and grain protein concentration. Increasing TaGS2 expression enhanced N uptake before and after anthesis, and allocated more $\mathrm{N}$ to grains, showing its crucial role in breeding $\mathrm{N}$ efficient wheat ideotype. The nitrate transporter TaNRT2.5-3B, and the transcription factors TaNFYA$6 B$ and TaNAC2-5A enhanced root growth as well as nitrate influx rate of wheat seedlings, and thus increased spike number and grain yield. This working model was derived from the study by [27]. DPA days postanthesis, $P n$ net photosynthesis rate. 


\section{Future Perspectives}

The goal of improving NUE is to maximize yield potential and GPC economically and environmentally friendly. To achieve this goal, it is required to understand at the molecular level how $\mathrm{N}$ signals affect tiller/spike number, spikelet number per spike, fertile floret per spikelet, and allocation of assimilates to grains. Although a larger number of QTL for N use- and yield-related traits and $\mathrm{N}$-responsive genes have been reported, only a few of them have been molecularly characterized owing to wheat's huge and complicated genome. Considering the complex gene network governing NUE and yield, and the relatively small number of primary $\mathrm{N}$ assimilation genes, identification of genes regulating the expression and activity of primary $\mathrm{N}$ assimilation genes will facilitate wheat breeding with improve NUE, yield, and GPC through marker-assisted selection and genome editing approaches.

Author Contributions: W.T. and Y.T. wrote the manuscript, W.T. and X.H. performed analysis in Tables 1 and 2. All authors have read and agreed to the published version of the manuscript.

Funding: This research was supported by the Strategic Priority Research Program of Chinese Academy of Sciences, Grant No. XDA24010202, and the National Natural Science Foundation of China, Grant No. 32072660.

Institutional Review Board Statement: Not applicable.

Informed Consent Statement: Not applicable.

Data Availability Statement: All data cited in the study are public available.

Conflicts of Interest: The authors declare no conflict of interest.

\section{References}

1. Shiferaw, B.; Smale, M.; Braun, H.-J.; Duveiller, E.; Reynolds, M.; Muricho, G. Crops that feed the world 10. Past successes and future challenges to the role played by wheat in global food security. Food Secur. 2013, 5, 291-317. [CrossRef]

2. Wheat Initiative's Strategic Research Agenda. Available online: https://www.wheatinitiative.org/strategic-research-agenda (accessed on 25 December 2021).

3. Tilman, D.; Cassman, K.G.; Matson, P.A.; Naylor, R.; Polasky, S. Agricultural sustainability and intensive production practices. Nature 2002, 418, 671-677. [CrossRef] [PubMed]

4. Heffer, P.; Gruère, A.; Roberts, T. Assessment of Fertilizer Use by Crop at the Global Level; International Fertilizer Association and International Plant Nutrition Institute: Norcross, GA, USA, 2017; pp. 1-18.

5. Lassaletta, L.; Billen, G.; Grizzetti, B.; Anglade, J.; Garnier, J. 50 year trends in nitrogen use efficiency of world cropping systems: The relationship between yield and nitrogen input to cropland. Environ. Res. Lett. 2014, 9, 105011. [CrossRef]

6. Byrnes, B.H. Environmental effects of $\mathrm{n}$ fertilizer use-an overview. Fert. Res. 1990, 26, 209-215. [CrossRef]

7. Swarbreck, S.M.; Wang, M.; Wang, Y.; Kindred, D.; Sylvester-Bradley, R.; Shi, W.; Varinderpal, S.; Bentley, A.R.; Griffiths, H. A roadmap for lowering crop nitrogen requirement. Trends Plant Sci. 2019, 24, 892-904. [CrossRef]

8. Cormier, F.; Foulkes, J.; Hirel, B.; Gouache, D.; Moenne-Loccoz, Y.; Le Gouis, J. Breeding for increased nitrogen-use efficiency: A review for wheat (T. aestivum L.). Plant Breed. 2016, 135, 255-278. [CrossRef]

9. Hawkesford, M.J.; Araus, J.-L.; Park, R.; Calderini, D.; Miralles, D.; Shen, T.; Zhang, J.; Parry, M.A.J. Prospects of doubling global wheat yields. Food Energy Secur. 2013, 2, 34-48. [CrossRef]

10. Islam, S.; Zhang, J.; Zhao, Y.; She, M.; Ma, W. Genetic regulation of the traits contributing to wheat nitrogen use efficiency. Plant Sci. 2021, 303, 110759. [CrossRef]

11. Saini, D.K.; Chopra, Y.; Pal, N.; Chahal, A.; Srivastava, P.; Gupta, P.K. Meta-qtls, ortho-mqtls and candidate genes for nitrogen use efficiency and root system architecture in bread wheat (Triticum aestivum L.). Physiol. Mol. Biol. Plants 2021, 27, $2245-2267$. [CrossRef]

12. Moll, R.H.; Kamprath, E.J.; Jackson, W.A. Analysis and interpretation of factors which contribute to efficiency of nitrogenutilization. Agron. J. 1982, 74, 562-564. [CrossRef]

13. Ivić, M.; Grljušić, S.; Plavšin, I.; Dvojković, K.; Lovrić, A.; Rajković, B.; Maričević, M.; Černe, M.; Popović, B.; Lončarić, Z.; et al. Variation for nitrogen use efficiency traits in wheat under contrasting nitrogen treatments in south-eastern europe. Front. Plant Sci. 2021, 12, 682333. [CrossRef] [PubMed]

14. Liu, L.; Sadras, V.O.; Xu, J.; Hu, C.; Yang, X.; Zhang, S. Chapter five-genetic improvement of crop yield, grain protein and nitrogen use efficiency of wheat, rice and maize in china. In Advances in Agronomy; Sparks, D.L., Ed.; Academic Press: Cambridge, MA, USA, 2021; Volume 168, pp. 203-252. 
15. Cormier, F.; Faure, S.; Dubreuil, P.; Heumez, E.; Beauchene, K.; Lafarge, S.; Praud, S.; Le Gouis, J. A multi-environmental study of recent breeding progress on nitrogen use efficiency in wheat (Triticum aestivum L.). Appl. Genet. 2013, 126, 3035-3048. [CrossRef] [PubMed]

16. Guttieri, M.J.; Frels, K.; Regassa, T.; Waters, B.M.; Baenziger, P.S. Variation for nitrogen use efficiency traits in current and historical great plains hard winter wheat. Euphytica 2017, 213, 87. [CrossRef]

17. Miflin, B.J.; Habash, D.Z. The role of glutamine synthetase and glutamate dehydrogenase in nitrogen assimilation and possibilities for improvement in the nitrogen utilization of crops. J. Exp. Bot. 2002, 53, 979-987. [CrossRef]

18. Li, M.; Tian, H.; Gao, Y. A genome-wide analysis of npf and nrt2 transporter gene families in bread wheat provides new insights into the distribution, function, regulation and evolution of nitrate transporters. Plant Soil 2021, 465, 47-63. [CrossRef]

19. Wang, H.; Wan, Y.; Buchner, P.; King, R.; Ma, H.; Hawkesford, M.J. Phylogeny and gene expression of the complete nitrate transporter 1/peptide transporter family in Triticum aestivum. J. Exp. Bot. 2020, 71, 4531-4546. [CrossRef]

20. Hu, B.; Wang, W.; Ou, S.; Tang, J.; Li, H.; Che, R.; Zhang, Z.; Chai, X.; Wang, H.; Wang, Y.; et al. Variation in $n r t 1.1 b$ contributes to nitrate-use divergence between rice subspecies. Nat. Genet. 2015, 47, 834-838. [CrossRef]

21. Li, W.; He, X.; Chen, Y.; Jing, Y.; Shen, C.; Yang, J.; Teng, W.; Zhao, X.; Hu, W.; Hu, M.; et al. A wheat transcription factor positively sets seed vigour by regulating the grain nitrate signal. New Phytol. 2020, 225, 1667-1680. [CrossRef]

22. Li, M.; Wang, T.; Zhang, H.; Liu, S.; Li, W.; Abou Elwafa, S.F.; Tian, H. Tanrt2.1-6b is a dual-affinity nitrate transporter contributing to nitrogen uptake in bread wheat under both nitrogen deficiency and sufficiency. Crop. J. 2022, 12, 16. [CrossRef]

23. Yang, Y.; Amo, A.; Wei, D.; Chai, Y.; Zheng, J.; Qiao, P.; Cui, C.; Lu, S.; Chen, L.; Hu, Y.G. Large-scale integration of meta-qtl and genome-wide association study discovers the genomic regions and candidate genes for yield and yield-related traits in bread wheat. Appl. Genet. 2021, 134, 3083-3109. [CrossRef]

24. Liu, H.; Mullan, D.; Zhang, C.; Zhao, S.; Li, X.; Zhang, A.; Lu, Z.; Wang, Y.; Yan, G. Major genomic regions responsible for wheat yield and its components as revealed by meta-qtl and genotype-phenotype association analyses. Planta 2020, 252, 65. [CrossRef] [PubMed]

25. Quraishi, U.M.; Abrouk, M.; Murat, F.; Pont, C.; Foucrier, S.; Desmaizieres, G.; Confolent, C.; Riviere, N.; Charmet, G.; Paux, E.; et al . Cross-genome map based dissection of a nitrogen use efficiency ortho-metaqtl in bread wheat unravels concerted cereal genome evolution. Plant J. 2011, 65, 745-756. [CrossRef] [PubMed]

26. Li, X.-P.; Zhao, X.-Q.; He, X.; Zhao, G.-Y.; Li, B.; Liu, D.-C.; Zhang, A.-M.; Zhang, X.-Y.; Tong, Y.-P.; Li, Z.-S. Haplotype analysis of the genes encoding glutamine synthetase plastic isoforms and their association with nitrogen-use- and yield-related traits in bread wheat. New Phytol. 2011, 189, 449-458. [CrossRef] [PubMed]

27. Hu, M.Y.; Zhao, X.Q.; Liu, Q.; Hong, X.; Zhang, W.; Zhang, Y.J.; Sun, L.J.; Li, H.; Tong, Y.P. Transgenic expression of plastidic glutamine synthetase increases nitrogen uptake and yield in wheat. Plant Biotechnol. J. 2018, 16, 1858-1867. [CrossRef] [PubMed]

28. Yang, J.; Wang, M.; Li, W.; He, X.; Teng, W.; Ma, W.; Zhao, X.; Hu, M.; Li, H.; Zhang, Y.; et al. Reducing expression of a nitrate-responsive bzip transcription factor increases grain yield and $\mathrm{n}$ use in wheat. Plant Biotechnol. J. 2019, 17, 1823-1833. [CrossRef]

29. Gao, Z.Y.; Wang, Y.F.; Chen, G.; Zhang, A.P.; Yang, S.L.; Shang, L.G.; Wang, D.Y.; Ruan, B.P.; Liu, C.L.; Jiang, H.Z.; et al. The indica nitrate reductase gene osnr2 allele enhances rice yield potential and nitrogen use efficiency. Nat. Commun. 2019, $10,5207$. [CrossRef]

30. Nishimura, A.; Ashikari, M.; Lin, S.; Takashi, T.; Angeles, E.R.; Yamamoto, T.; Matsuoka, M. Isolation of a rice regeneration quantitative trait loci gene and its application to transformation systems. Proc. Natl. Acad. Sci. USA 2005, 102, 11940-11944. [CrossRef]

31. Yu, J.; Xuan, W.; Tian, Y.; Fan, L.; Sun, J.; Tang, W.; Chen, G.; Wang, B.; Liu, Y.; Wu, W.; et al. Enhanced osnlp4-osnir cascade confers nitrogen use efficiency by promoting tiller number in rice. Plant Biotechnol. J. 2021, 19, 167-176. [CrossRef]

32. Martin, A.; Lee, J.; Kichey, T.; Gerentes, D.; Zivy, M.; Tatout, C.; Dubois, F.; Balliau, T.; Valot, B.; Davanture, M.; et al. Two cytosolic glutamine synthetase isoforms of maize are specifically involved in the control of grain production. Plant Cell 2006, 18, 3252-3274. [CrossRef]

33. Langridge, P.; Reynolds, M. Breeding for drought and heat tolerance in wheat. Appl. Genet. 2021, 134, 1753-1769. [CrossRef]

34. Nagy, Z.; Nemeth, E.; Guoth, A.; Bona, L.; Wodala, B.; Pecsvaradi, A. Metabolic indicators of drought stress tolerance in wheat: Glutamine synthetase isoenzymes and rubisco. Plant Physiol. Bioch. 2013, 67, 48-54. [CrossRef] [PubMed]

35. Khan, M.I.; Iqbal, N.; Masood, A.; Per, T.S.; Khan, N.A. Salicylic acid alleviates adverse effects of heat stress on photosynthesis through changes in proline production and ethylene formation. Plant Signal. Behav. 2013, 8, e26374. [CrossRef] [PubMed]

36. Russell, K.; Van Sanford, D. Breeding for resilience to increasing temperatures: A field trial assessing genetic variation in soft red winter wheat. Ecol. Evol. 2018, 8, 12090-12100. [CrossRef] [PubMed]

37. Yu, H.; Zhang, Y.; Zhang, Z.; Zhang, J.; Wei, Y.; Jia, X.; Wang, X.; Ma, X. Towards identification of molecular mechanism in which the overexpression of wheat cytosolic and plastid glutamine synthetases in tobacco enhanced drought tolerance. Plant Physiol. Bioch. 2020, 151, 608-620. [CrossRef]

38. Hyles, J.; Bloomfield, M.T.; Hunt, J.R.; Trethowan, R.M.; Trevaskis, B. Phenology and related traits for wheat adaptation. Heredity 2020, 125, 417-430. [CrossRef]

39. Abedi, T.; Alemzadeh, A.; Kazemeyni, S.A. Wheat yield and grain protein response to nitrogen amount and timing. Aust. J. Crop. Sci. 2011, 5, 327-333. 
40. Duan, J.; Wu, Y.; Zhou, Y.; Ren, X.; Shao, Y.; Feng, W.; Zhu, Y.; Wang, Y.; Guo, T. Grain number responses to pre-anthesis dry matter and nitrogen in improving wheat yield in the huang-huai plain. Sci. Rep. 2018, 8, 7126. [CrossRef]

41. Zhang, Z.; Li, J.; Hu, N.; Li, W.; Qin, W.; Li, J.; Gao, Y.; Liu, Y.; Sun, Z.; Yu, K.; et al. Spike growth affects spike fertility through the number of florets with green anthers before floret abortion in wheat. Field Crops Res. 2021, 260, 108007. [CrossRef]

42. Ewert, F.; Honermeier, B. Spikelet initiation of winter triticale and winter wheat in response to nitrogen fertilization. Eur. J. Agron. 1999, 11, 107-113. [CrossRef]

43. Daigger, L.A.; Sander, D.H. Nitrogen availability to wheat as affected by depth of nitrogen placement. Agron. J. 1976, 68, 524-526. [CrossRef]

44. Liao, M.; Fillery, I.R.; Palta, J.A. Early vigorous growth is a major factor influencing nitrogen uptake in wheat. Funct. Plant Biol. 2004, 31, 121-129. [CrossRef] [PubMed]

45. Peng, C.; Zhang, Z.; Li, Y.; Zhang, Y.; Dong, H.; Fang, Y.; Han, L.; Xu, W.; Hu, L. Genetic improvement analysis of nitrogen uptake, utilization, translocation, and distribution in chinese wheat in henan province. Field Crop. Res. 2022, 277, 108406. [CrossRef]

46. Tian, Z.; Li, Y.; Liang, Z.; Guo, H.; Cai, J.; Jiang, D.; Cao, W.; Dai, T. Genetic improvement of nitrogen uptake and utilization of winter wheat in the yangtze river basin of china. Field Crops Res. 2016, 196, 251-260. [CrossRef]

47. Lynch, J.P. Steep, cheap and deep: An ideotype to optimize water and $\mathrm{n}$ acquisition by maize root systems. Ann. Bot. Lond. 2013, 112, 347-357. [CrossRef] [PubMed]

48. Giehl, R.F.; von Wiren, N. Root nutrient foraging. Plant Physiol. 2014, 166, 509-517. [CrossRef]

49. Shao, A.; Ma, W.Y.; Zhao, X.Q.; Hu, M.Y.; He, X.; Teng, W.; Li, H.; Tong, Y.P. The auxin biosynthetic Tryptophan aminotransferase related tatar2.1-3a increases grain yield of wheat. Plant Physiol. 2017, 174, 2274-2288. [CrossRef]

50. Ma, W.; Li, J.; Qu, B.; He, X.; Zhao, X.; Li, B.; Fu, X.; Tong, Y. Auxin biosynthetic gene tar2 is involved in low nitrogen-mediated reprogramming of root architecture in arabidopsis. Plant $J .2014,78,70-79$. [CrossRef]

51. Zhang, S.; Zhu, L.; Shen, C.; Ji, Z.; Zhang, H.; Zhang, T.; Li, Y.; Yu, J.; Yang, N.; He, Y.; et al. Natural allelic variation in a modulator of auxin homeostasis improves grain yield and nitrogen use efficiency in rice. Plant Cell 2021, 33, 566-580. [CrossRef]

52. Ren, Y.; He, X.; Liu, D.; Li, J.; Zhao, X.; Li, B.; Tong, Y.; Zhang, A.; Li, Z. Major quantitative trait loci for seminal root morphology of wheat seedlings. Mol. Breed. 2012, 30, 139-148. [CrossRef]

53. Cao, P.; Ren, Y.Z.; Zhang, K.P.; Teng, W.; Zhao, X.Q.; Dong, Z.Y.; Liu, X.; Qin, H.J.; Li, Z.S.; Wang, D.W.; et al. Further genetic analysis of a major quantitative trait locus controlling root length and related traits in common wheat. Mol. Breed. 2014, 33, 975-985. [CrossRef]

54. Xu, Y.F.; Wang, R.F.; Tong, Y.P.; Zhao, H.T.; Xie, Q.G.; Liu, D.C.; Zhang, A.M.; Li, B.; Xu, H.X.; An, D.G. Mapping qtls for yield and nitrogen-related traits in wheat: Influence of nitrogen and phosphorus fertilization on qtl expression. Appl. Genet. 2014, 127, 59-72. [CrossRef] [PubMed]

55. Fan, X.L.; Zhang, W.; Zhang, N.; Chen, M.; Zheng, S.S.; Zhao, C.H.; Han, J.; Liu, J.J.; Zhang, X.L.; Song, L.Q.; et al. Identification of $\mathrm{qtl}$ regions for seedling root traits and their effect on nitrogen use efficiency in wheat (Triticum aestivum L.). Appl. Genet. 2018, 131, 2677-2698. [CrossRef] [PubMed]

56. Liu, J.; Zhang, Q.; Meng, D.; Ren, X.; Li, H.; Su, Z.; Zhang, N.; Zhi, L.; Ji, J.; Li, J.; et al. Qmrl-7b enhances root system, biomass, nitrogen accumulation and yield in bread wheat. Plants 2021, 10, 764. [CrossRef] [PubMed]

57. Qu, B.Y.; He, X.; Wang, J.; Zhao, Y.Y.; Teng, W.; Shao, A.; Zhao, X.Q.; Ma, W.Y.; Wang, J.Y.; Li, B.; et al. A wheat ccaat box-binding transcription factor increases the grain yield of wheat with less fertilizer input. Plant Physiol. 2015, 167, 411-423. [CrossRef]

58. He, X.; Qu, B.; Li, W.; Zhao, X.; Teng, W.; Ma, W.; Ren, Y.; Li, B.; Li, Z.; Tong, Y. The nitrate-inducible nac transcription factor tanac2-5a controls nitrate response and increases wheat yield. Plant Physiol. 2015, 169, 1991-2005. [CrossRef] [PubMed]

59. Pang, J.; Milroy, S.P.; Rebetzke, G.J.; Palta, J.A. The influence of shoot and root size on nitrogen uptake in wheat is affected by nitrate affinity in the roots during early growth. Funct. Plant Biol. 2015, 42, 1179-1189. [CrossRef]

60. Wang, Q.; Nian, J.; Xie, X.; Yu, H.; Zhang, J.; Bai, J.; Dong, G.; Hu, J.; Bai, B.; Chen, L.; et al. Genetic variations in are1 mediate grain yield by modulating nitrogen utilization in rice. Nat. Commun. 2018, 9, 735. [CrossRef]

61. Zhang, J.; Zhang, H.; Li, S.; Li, J.; Yan, L.; Xia, L. Increasing yield potential through manipulating of an are1 ortholog related to nitrogen use efficiency in wheat by crispr/cas9. J. Integr. Plant Biol. 2021, 63, 1649-1663. [CrossRef]

62. Taulemesse, F.; Le Gouis, J.; Gouache, D.; Gibon, Y.; Allard, V. Post-flowering nitrate uptake in wheat is controlled by n status at flowering, with a putative major role of root nitrate transporter nrt2.1. PLoS ONE 2015, 10, e0120291. [CrossRef]

63. Bogard, M.; Allard, V.; Brancourt-Hulmel, M.; Heumez, E.; Machet, J.M.; Jeuffroy, M.H.; Gate, P.; Martre, P.; Le Gouis, J. Deviation from the grain protein concentration-grain yield negative relationship is highly correlated to post-anthesis $\mathrm{n}$ uptake in winter wheat. J. Exp. Bot. 2010, 61, 4303-4312. [CrossRef]

64. Monaghan, J.M.; Snape, J.W.; Chojecki, A.J.S.; Kettlewell, P.S. The use of grain protein deviation for identifying wheat cultivars with high grain protein concentration and yield. Euphytica 2001, 122, 309-317. [CrossRef]

65. Nigro, D.; Gadaleta, A.; Mangini, G.; Colasuonno, P.; Marcotuli, I.; Giancaspro, A.; Giove, S.L.; Simeone, R.; Blanco, A. Candidate genes and genome-wide association study of grain protein content and protein deviation in durum wheat. Planta 2019, 249, 1157-1175. [CrossRef] [PubMed]

66. Cormier, F.; Le Gouis, J.; Dubreuil, P.; Lafarge, S.; Praud, S. A genome-wide identification of chromosomal regions determining nitrogen use efficiency components in wheat (Triticum aestivum L.). Appl. Genet. 2014, 127, 2679-2693. [CrossRef] [PubMed] 
67. Nehe, A.S.; Misra, S.; Murchie, E.H.; Chinnathambi, K.; Singh Tyagi, B.; Foulkes, M.J. Nitrogen partitioning and remobilization in relation to leaf senescence, grain yield and protein concentration in indian wheat cultivars. Field Crop. Res. 2020, 251 , 107778. [CrossRef]

68. Suprayogi, Y.; Clarke, J.M.; Bueckert, R.; Clarke, F.R.; Pozniak, C.J. Nitrogen remobilization and post-anthesis nitrogen uptake in relation to elevated grain protein concentration in durum wheat. Can. J. Plant Sci. 2011, 91, 273-282. [CrossRef]

69. Lamichhane, S.; Murata, C.; Griffey, C.A.; Thomason, W.E.; Fukao, T. Physiological and molecular traits associated with nitrogen uptake under limited nitrogen in soft red winter wheat. Plants 2021, 10, 165. [CrossRef]

70. Ryan, P.R.; Liao, M.; Delhaize, E.; Rebetzke, G.J.; Weligama, C.; Spielmeyer, W.; James, R.A. Early vigour improves phosphate uptake in wheat. J. Exp. Bot. 2015, 66, 7089-7100. [CrossRef]

71. Ehdaie, B.; Merhaut, D.J.; Ahmadian, S.; Hoops, A.C.; Khuong, T.; Layne, A.P.; Waines, J.G. Root system size influences water-nutrient uptake and nitrate leaching potential in wheat. J. Agron. Crop. Sci. 2010, 196, 455-466. [CrossRef]

72. Waines, J.G.; Ehdaie, B. Domestication and crop physiology: Roots of green-revolution wheat. Ann. Bot. Lond 2007, 100, 991-998. [CrossRef]

73. Voss-Fels, K.P.; Robinson, H.; Mudge, S.R.; Richard, C.; Newman, S.; Wittkop, B.; Stahl, A.; Friedt, W.; Frisch, M.; Gabur, I.; et al. Vernalization1 modulates root system architecture in wheat and barley. Mol. Plant 2018, 11, 226-229. [CrossRef]

74. Lei, L.; Li, G.; Zhang, H.; Powers, C.; Fang, T.; Chen, Y.; Wang, S.; Zhu, X.; Carver, B.F.; Yan, L. Nitrogen use efficiency is regulated by interacting proteins relevant to development in wheat. Plant Biotechnol. J. 2018, 16, 1214-1226. [CrossRef] [PubMed]

75. Kichey, T.; Heumez, E.; Pocholle, D.; Pageau, K.; Vanacker, H.; Dubois, F.; Le Gouis, J.; Hirel, B. Combined agronomic and physiological aspects of nitrogen management in wheat highlight a central role for glutamine synthetase. New Phytol. 2006, 169, 265-278. [CrossRef] [PubMed]

76. Habash, D.Z.; Massiah, A.J.; Rong, H.L.; Wallsgrove, R.M.; Leigh, R.A. The role of cytosolic glutamine synthetase in wheat. Ann. Appl. Biol. 2001, 138, 83-89. [CrossRef]

77. Bernard, S.M.; Moller, A.L.; Dionisio, G.; Kichey, T.; Jahn, T.P.; Dubois, F.; Baudo, M.; Lopes, M.S.; Terce-Laforgue, T.; Foyer, C.H.; et al. Gene expression, cellular localisation and function of glutamine synthetase isozymes in wheat (Triticum aestivum L.). Plant Mol. Biol. 2008, 67, 89-105. [CrossRef] [PubMed]

78. Zhang, Z.Y.; Xiong, S.P.; Wei, Y.H.; Meng, X.D.; Wang, X.C.; Ma, X.M. The role of glutamine synthetase isozymes in enhancing nitrogen use efficiency of n-efficient winter wheat. Sci. Rep. 2017, 7, 1000. [CrossRef]

79. Chardon, F.; Noel, V.; Masclaux-Daubresse, C. Exploring nue in crops and in arabidopsis ideotypes to improve yield and seed quality. J. Exp. Bot. 2012, 63, 3401-3412. [CrossRef]

80. Jain, V.; Khetarpal, S.; Das, R.; Abrol, Y.P. Nitrate assimilation in contrasting wheat genotypes. Physiol. Mol. Biol. Plants Int. J. Funct. Plant Biol. 2011, 17, 137-144. [CrossRef]

81. Zhao, X.Q.; Nie, X.L.; Xiao, X.G. Over-expression of a tobacco nitrate reductase gene in wheat (Triticum aestivum L.) increases seed protein content and weight without augmenting nitrogen supplying. PLoS ONE 2013, 8, e74678. [CrossRef] 